\title{
BEHAVIOUR OF HOLLOW CONCRETE-FILLED STEEL TUBULAR COMPOSITE ELEMENTS
}

\author{
Artiomas Kuranovas $^{1}$, Audronis Kazimieras Kvedaras ${ }^{2}$ \\ Dept of Steel and Timber Structures, Vilnius Gediminas Technical University, \\ Saul tekio al. 11, LT-10223 Vilnius, Lithuania \\ E-mail: ${ }^{1}$ artiomas@stst.vtu.lt; ${ }^{2} a k v e @ s t . v t u . l t$
}

Received 8 Aug 2006; accepted 6 Oct 2006

\begin{abstract}
Behaviour of composite steel-concrete elements in various loading stages is quite well analysed by theoretical investigations and experiments. Concrete-Filled Steel Tube (CFST) is one of many composite elements used at present in civil engineering. Different approaches and design philosophies were adopted in different design codes for it. But for hollow CFST elements, which are more effective than ordinary CFST, any code does not provide information about how to design these elements. Further investigations of hollow composite CFST elements are needed. In loading stage, when a particular level of stresses exists, an interaction between steel tube and concrete core appears and therefore a complex stress state of element takes place, which increases the load-bearing capacity of the whole composite element. This interaction between components of CFST elements is reached because of different material properties, such as Poisson's ratio, elasticity modulus etc. In this article reasons of the above-mentioned complex stress state appearance and behaviour of hollow CFST element components in different load stages of compressed stub structural member are analysed. The test results are presented in diagrams, tables. Previous researches of other investigators are summarised. Differences and similarities in behaviour of solid concrete and composite elements and hollow members with different number of concrete core layers are discussed.
\end{abstract}

Keywords: composite structures, centrifuging, hollow concrete-filled steel tubes, interaction of components, behaviour, concrete triaxial stress state, Poisson's ratio, micro-cracking.

\section{Introduction}

Steel members have the advantages of high tensile strength and ductility, while concrete members may be advantageous in compressive strength and stiffness. Many researchers agree that CFST members utilise the advantages of both steel and concrete [1]. They are comprised of a steel hollow section of circular or rectangular shape filled or centrifuged with plain or reinforced concrete (Fig 1).

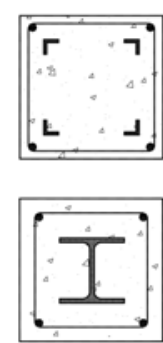

a)
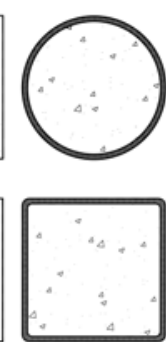

b)

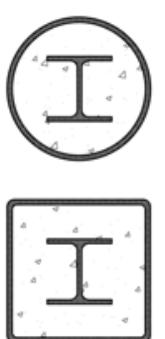

c)
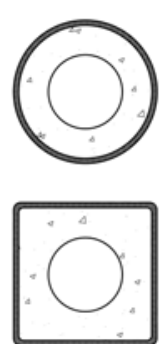

d)
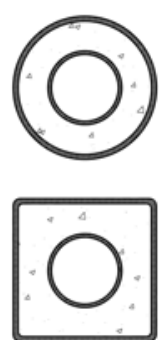

e)
Fig 1. Various types of composite columns: concrete encased steel (CES) (a), CFST (b), combination of CES and CFST (c), hollow CFST sections (d) and double skin sections (e)
CFST columns have many advantages over reinforced concrete columns. The major benefits of concrete filled columns are: a) steel column acts as a permanent and integral formwork; b) steel column provides external reinforcement, c) steel column supports several levels of construction prior to concrete being pumped and d) higher strength and stiffness compare with RC columns of the same materials properties.

The main effect of concrete is that it delays the local buckling of the tube wall and the concrete itself, in the restrained state, and is able to sustain higher stresses and strains when unrestrained.

A hollow CFST member has some advantages in respect of a solid CFST: a) a lower concrete consumption and total permanent load to building, b) inside columns can pipes, cables and other services of the building be installed, c) higher relative compressive strength, d) easier and cheaper assembling.

Hollow CFTS members can be also produced with a concentrically layered concrete core (double layered, triple layered etc) that increases the strength capacity of the whole member [2].

These composite columns can be also used for the resisting outside pressure, such as ocean waves, ice; in seismic regions because of excellent earthquake-resistant properties such as high strength, high ductility, and large energy absorption capacity. 
Different approaches and design philosophies have been adopted in different design codes [3]. In Japan, the standard for designing of composite columns is based on a simple method of superposition that uses the allowable stresses of the materials or the working stress method. ACI-318 adopts the traditional reinforced concrete approach. AS 3600-1994 also uses the concept of reinforced concrete design. The AISC-LRFD is based on the concept of structural steel. The Eurocode 4, being a dedicated code for composite construction, combined the design approach of both structural steelwork and reinforced concrete columns. All these codes provide a design procedure just for CFST, CES composite columns and any code does not mention hollow CFST elements. Generally, these codes are adopted for hollow section as for solid member.

Concentrically layered hollow CFST elements (Fig 2b) are more effective than ordinary hollow elements, because of the interaction between surfaces of concrete layers which appears after spinning [4]. This interaction appears independently on the type of loading applied to such hollow CFTS element and on the increased load-bearing capacity of components [5].

As mentioned above, there exists between CFST components some interaction and any code does not take it into account, except for confinement effect and average interface shear stress associated with the residual load due to friction. Any adhesive bond is taken into account.
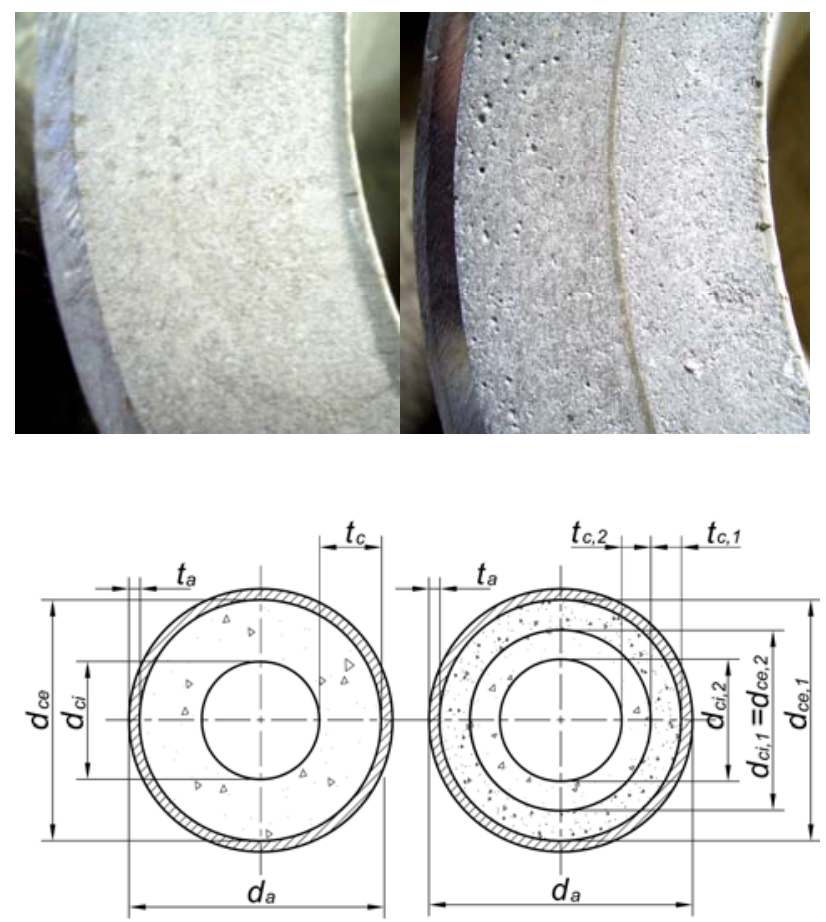

a)

b)

Fig 2. Cross-section of CFTS element with (a) single- and (b) double layered concrete core

So at present it is a lack of information for designers. Further investigations, tests, FEM and structural analyses are necessary.

\section{Structural behaviour of hollow CFTS columns}

Many researchers agree that most composite structural elements are subjected to a multi-axial stress state [3]. The response of concrete in CFST elements varies widely for different stress states, and it is therefore important to know how the concrete behaves in different multi-axial stress states.

The structural behaviour of hollow CFST members is complex because of the interaction between the steel tubular shell and the hollow concrete core. The pioneer test research effort on the structural behaviour of CFST members was made by J. S. Sewel [6]. He observed that the ultimate axial resistance of CFST columns is greater than the sum of resistance of separately tested steel and concrete components. Further investigations of CFST elements were performed by a great number of researchers of whom K.Klöppel and W.Goder [7], H. R. Salani and J. R. Sims [8], R. W. Furlong [9] may be mentioned. Their investigations discovered that the increase in load-bearing capacity of CFST elements is mainly caused by the confining effect of steel tube on the concrete core. The different Poisson's ratios of steel tube and concrete core are considerably affected by the structural behaviour of CFST elements.

Almost all researchers agreed that during the initial loading stage (as for solid as well as for hollow CFST members) the concrete Poisson's ratio is lower than that of steel (Fig 3a), and the steel tube has no confining effect on the concrete core. As longitudinal strains increase, the lateral expansion of concrete gradually becomes greater than that of steel tube (Fig 3b). Hoop and radial stresses are equal. At this stage, it is considered that the steel tube becomes bi-axially and solid concrete core triaxially stressed [10, 11], but for the hollow CFST 3D

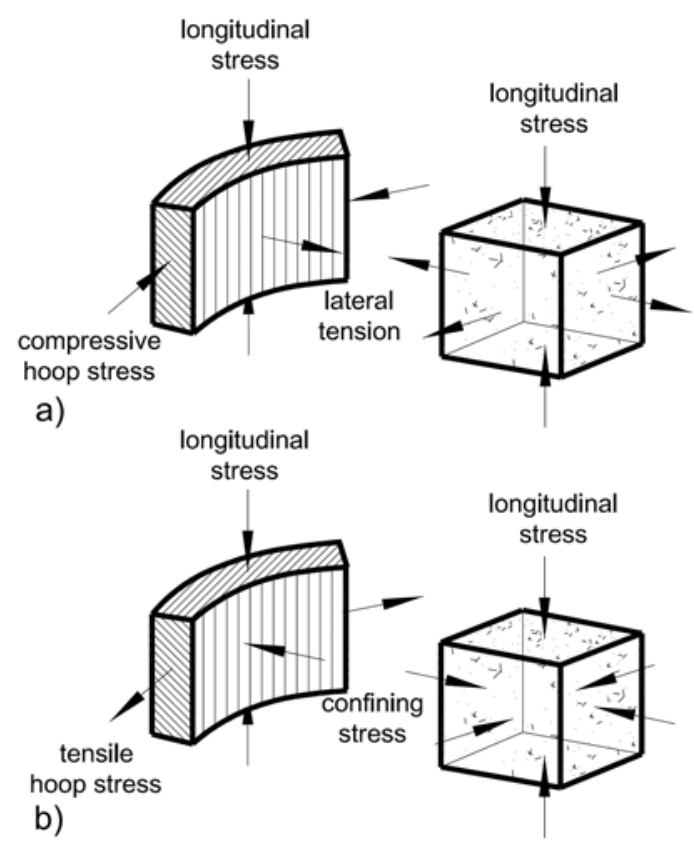

Fig 3. Stress condition in steel tube and concrete core at different stages of loading: $v_{a}>v_{c}(a), v_{a}<v_{c}$ (b) 
stress state is on the inside concrete core and steel tube interface. At the same time, the steel is compressed in the longitudinal, radial and is tensioned in the hoop directions. For double-layered CFST (especially for layers from different concrete grades) the greater transversal deformations of internal layer cause lateral pressure on the external core layer. Thus stresses of both concrete layers redistribute, and on external concrete core layer maybe analysed as behaving in triaxial and internal, core layer - in biaxial states. On the other hand, researchers [12] suggest for axially and laterally compressed solid body to consider biaxial stress state as a simplified model of triaxial state.

In the first stage of axial compression the steel tube as a component of CFST element sustains a greater part of the load until it starts yielding. At this point a load transfer from steel tube to the concrete core starts, and a further increase of load is exhibited by only concrete core until it reaches its micro-cracking compressive strength $[5,13,14]$. After this stage of loading, a redistribution of load from concrete core to the steel tube takes place. At this point the steel exhibits a hardening behaviour as in an uniaxial stress-strain hardening relationship.

The theoretical and practical investigations according to [14] show that the behaviour of concrete in CFST elements becomes more ductile with lateral pressure increasing due to delaying micro-cracking. It is also interpreted that during compression the force transfer through concrete core is accomplished by bridging forces between the aggregates, and to a large extent by shear stresses, which are transferred over more or less inclined microcracks. The lateral pressure force balances the bridging forces that reduce the tensile force and thereby delay the rise and growth of bond cracks, therefore formation of cracks becomes more difficult. According to [14], when cracks are present, the confining stress will slow down shear sliding of cracks, due to an increase of the frictional shear stresses and stresses because of aggregate interlock. Furthermore, the reduced micro-cracking shear sliding leads to a less crack opening and thus reduces lateral expansion. A delayed damage due to confining pressure of maximum value is reached at zero volumetric strain of concrete.

Another point of view to micro-cracking of concrete composite members is presented in [15]. In composite steel and concrete structures, where one of main loadbearing components is concrete, at various loading stages appear its compaction, resolution and failure processes, which lead to micro-cracking. During loading of concrete usually two parametrical points $f_{c r}^{0}$ and $f_{c r}^{v}$ are fixed. Investigations allow defining consistent pattern relationships and various important concrete deformation processes between these points. $f_{c r}^{0}$ value of concrete strength notices the start of micro-cracking process and $f_{c r}^{v}$ fixing the moment when of relative volume increment reaches zero. Independence of concrete structure parametric point $f_{c r}^{v}$ is usually fixed when stresses in concrete core reach $0,5-0,8 f_{c}$ value. Then concrete vol- ume starts to increase, and at $v_{c} \geq v_{a}$ a concrete core begins to stress a steel tube. For a certain period the micro-crack propagation process starts slowing down. However, further load increase leads to concrete core pressure rising on the steel shell. This phenomenon is considered as one of the main reasons of strengthening the concrete confined in the steel tube. At parametric point $f_{c r}^{v}$ the increment of relative volume $\Delta \theta$ reaches zero, and transversal strains of concrete core start to increase significantly. It is experimentally determined [16, 17] that structure of loaded concrete depends on the specimen form. Concrete tubes have a greater micro-cracking level $f_{c r}^{v}$ than prism or cylindrical specimens, because the values of transversal and longitudinal strains of concrete tubes are 1,2-1,3 times greater on internal than on external surfaces. For CFST elements under compression a parametrical point $f_{c r}^{v}$ maybe determined by condition $\Delta \theta=0[16]:$

$$
\Delta \theta=\frac{d_{a}^{2}\left(\Delta \varepsilon_{1 m}-2 \Delta \varepsilon_{2 e}\right)-d_{c i}^{2}\left(\Delta \varepsilon_{1 m}-2 \Delta \varepsilon_{1 e}\right)}{d_{a}^{2}-d_{c i}^{2}},
$$

where $\Delta \varepsilon_{1 m}=\left(\Delta \varepsilon_{1 e}-\Delta \varepsilon_{1 i}\right) / 2-$ mean increment of relative longitudinal strains at hollow CFST element on the external $\Delta \varepsilon_{1 e}$ and internal $\Delta \varepsilon_{1 i}$ surfaces, determined at corresponding loading step $\Delta \sigma ; \Delta \varepsilon_{2 e}, \Delta \varepsilon_{2 i}$ - transversal strains at external and internal surfaces of element respectively.

For the behaviour determining CFST members under axial compression the problem of axial symmetry is used. The behaviour of axial loaded centrifuged CFST members is more complicated than of a solid, because none of stresses are uniformly distributed through the cross-section [5] (Fig 4a), but the stress distribution pattern in the steel tube is the same both in solid and hollow composite cross-sections [11].

For 3D stress state the strain-stress relationship may be represented by generalised Hook's law, and the expression of longitudinal strains is derived from it:

$$
\varepsilon_{z}=\left[\sigma_{z}-v\left(\sigma_{r}-\sigma_{t}\right)\right] / E \text {. }
$$

In plastic stage, the distribution of radial stress across hollow concrete core according to Lame problem maybe analysed as linear:

$$
\sigma_{\rho}=\sigma_{r}\left(r_{c e}-r_{c i}\right) /\left(r_{i}-r_{b i}\right) \text {. }
$$

The distribution of hoop stress $\sigma_{t}$ at plastic stage is due to rectangular diagram and its value defined by value of radial stresses due to Laplace equation:

$$
\sigma_{t}=\sigma_{r} \beta_{i} /\left(\beta_{i}-1\right)
$$

where $\beta_{i}=r_{c e} / r_{c i}$ - relative concrete core thickness.

Behaviour of multi-layered hollow CFST elements is more complicated than of single-layered ones because of additional interaction between concrete core layers (Figs 4 b, c). Eqs (2), (3) and (4) used for double-and triple-layered elements are valid only for the internal layer. As mentioned above, the 3D stress state is specific to external and media layers of hollow concrete core and stress determined as for solid member [5]. 


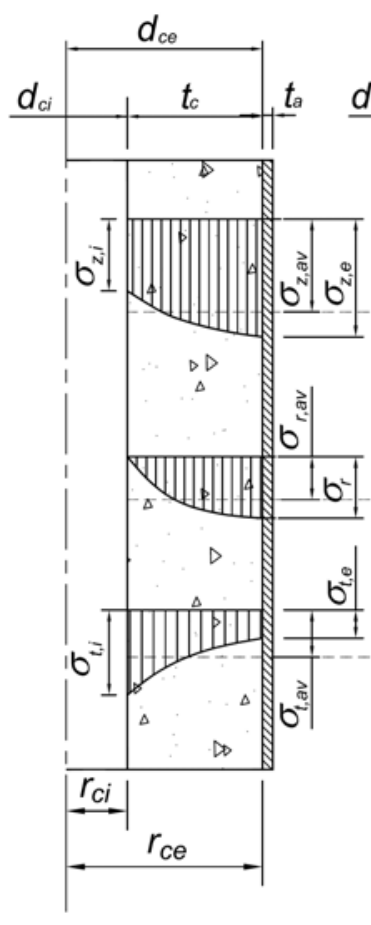

a)

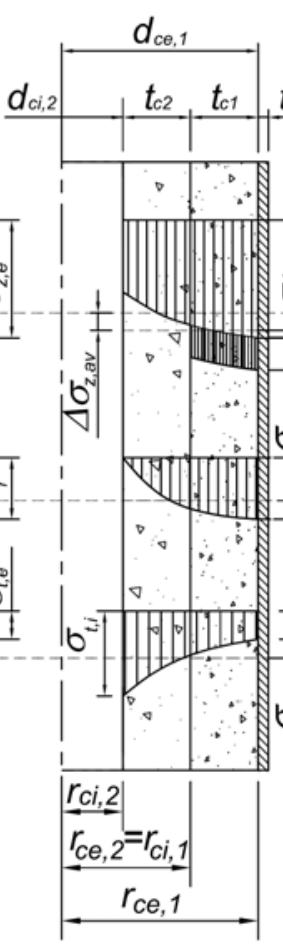

b)

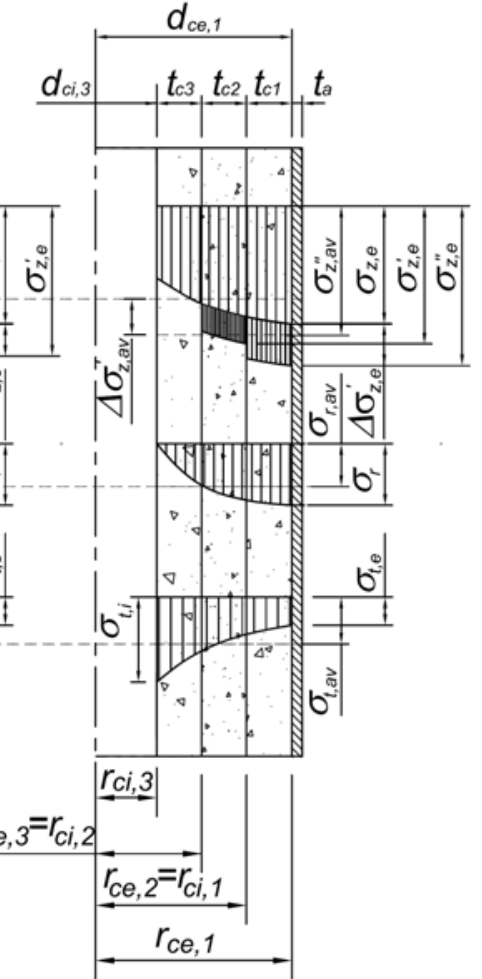

c)

Fig 4. Stress distribution in concrete core of centrifuged (a), one- (b) double-, and (c) triple-layered CFST elements

According to [18], diagrams of principal stresses of multi-layered CFST elements at contact surfaces (steelconcrete, concrete-concrete) are stepped because of changes in stiffness and appearance of additional internal forces in the area of contact between different concrete core layers (Figs $4 \mathrm{~b}, \mathrm{c}$ ). The shape of diagram remains the same as for single-layered element. Values of steps are determined by formula:

$$
\Delta \sigma_{i}=\tau_{i} / \xi_{i},
$$

where $\xi_{i}$ - experimentally determined coefficient of stiffness and $\tau_{i}$ - tangential stress in $i$-contact surface.

These steps are mathematically compensated [19]:

$$
\sigma_{z}=E_{j} N / A_{E},
$$

where $A_{E}=\iint_{A} E d x d y=\sum_{j} A_{j} E_{j}-$ stiffness of the whole element and $A_{j}, E_{j}-$ cross-sections and elasticity modulus of $j$ medium.

Difference in Poisson's ratios of composite element symmetrically composed from different materials during compression increases the load-bearing capacity of whole element independently of signs of components Poisson's ratios by increment of stiffness $K_{33}$ value:

$$
K_{33}=\iint_{A} \sigma_{z 0} d x d y>0,
$$

where $\sigma_{0}-$ axial stress of auxiliary problem plain deformation solution. So the increased axial stress in composite element is determined by (8):

$$
\sigma_{z}=E_{j} N /\left(A_{E} K_{33}\right) \text {. }
$$

According to [19] axial compression in composite element produced from the same material with different Poisson's ratios generate lower axial stresses, than in case of bar produced from different materials, but with same Poisson's ratios. Therefore the first component of composite bar can be loaded with a greater force until reaching the same axial stresses as in the second component. This is valid for elastic materials. As mentioned above, during compression a pressure to the tube appears. So for CFST elements a plastic stage starts at an internal layer and ends at the external one [19].

Some researchers pay attention to a more complex behaviour of CFST element and explain that during axial loading not only normal, radial and tangent stresses appear, but also shear stresses at surfaces between components of CFST $[18,20]$. The mechanisms by which shear stresses maybe transferred over the interface from steel tube to the concrete core and in opposite way are quite well described [9, 10, 14], and assessed as adhesion, interface interlocking and friction. These 3 mechanisms are often referred to as the natural bond [21-24].

\section{Experimental investigations}

\subsection{Properties of materials and specimens}

Steel circular hollow sections (CHS) were used in manufacturing the specimens. Yield and ultimate strength of CHS were determined by standard steel plate coupons and rings tests. The coupons and rings were cut off from each steel tube. According to test results the, S355 steel grade was found for CHS. The concrete mixture for single- and double-layered specimens was designed for 
compressive cube strength at 28 days of approx $30 \mathrm{MPa}$. The used mixture proportions are presented in Table 1. For fine aggregate the quartz sand of $0,2 \mathrm{~mm}$ main grain size and Portland cement of CEMII/A-L 42,5N grade as binder material were used. The initial cement/water ratio and slump of concrete cone were taken from recommendations [4], but because of very fine aggregates the required slump for centrifugation with these proportions of concrete components was not achieved. So for achieving the needed slump additional water was used (Table 1, number in brackets). After centrifuging the residual water quantity was measured, and it was obtained that during multi-layered centrifuging more residual water is pressed out from the concrete mixture. For determining the concrete, mechanical properties cubes and prisms were manufactured from the same concrete mix by vibrating. Single- and double-layered centrifuged CFST were cured in laboratory with environmental humidity of $21 \%$ and temperature $16,1^{\circ} \mathrm{C}$. Concrete cores in centrifuged specimens were isolated from environmental action by polyethylene film at the ends of steel tube. Internal environmental humidity was $82 \%$. CFST members after 28 days of curing were cut to smaller specimens of $\sim 437 \mathrm{~mm}$ in length. For determining the mechanical properties of single- and double-layered centrifuged concrete cores the steel shells from some specimens were taken off. Hollow concrete and CFST elements were tested under an axial compression.

\subsection{Force-strain relationships of different elements}

For the improvement that in hollow CFST elements during loading the stresses are redistributed in a complex way as mentioned above, there were manufactured and axially compressed specimens of annular cross-section: single- (1CFST) and double-layered (2CFST) CFST members (Fig 5c), single- (1CT) and double-layered (2CT) concrete members (Fig 5b) and empty steel tubes ST (Fig 5a). All their longitudinal $\varepsilon_{L}$ and transversal $\varepsilon_{T}$ strains measured by vertical and horizontal strain-gages, and load-bearing capacity were fixed by testing machine scale. These test results are presented in Table 2 and by $F-\varepsilon, F-v, v-\varepsilon$ diagrams (Figs 5-9).

The analysis of results shows that during multilayered centrifuging an interaction between components of CFST element appears and increases strength at least by $10 \%$. These results have shown that composite effect of singlelayered specimens was $\sim 6 \%$, for double-layered $\sim 12 \%$. Diagrams $F-\varepsilon$ of ST members are presented in Fig 5a from which can be noted that yield stresses appear near the value determined by testing of rings $f_{y, c}=340 \mathrm{MPa}$ and coupons $f_{y, t}=361 \mathrm{MPa}$. Buckling of ST members appears immediately after reaching the yield stresses.

Fig $5 \mathrm{~b}$ represents diagrams $F-\varepsilon$ of single- and double-layered CT. Curves 1, 1' in Figs 5b, c represent values of longitudinal and transversal strains measured on a single-layered internal, 3, $3^{\prime}$ on external concrete core

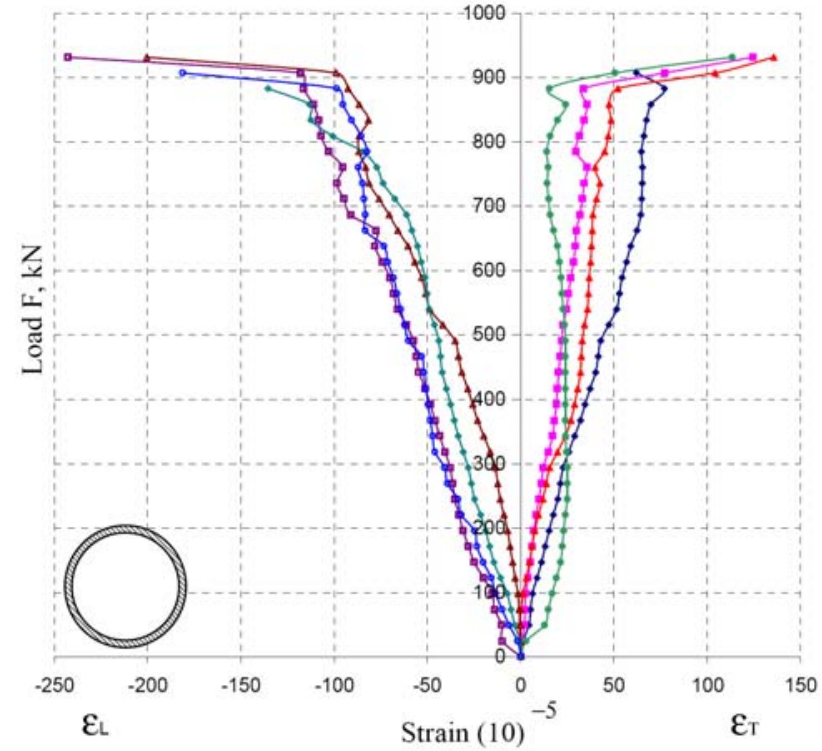

a)

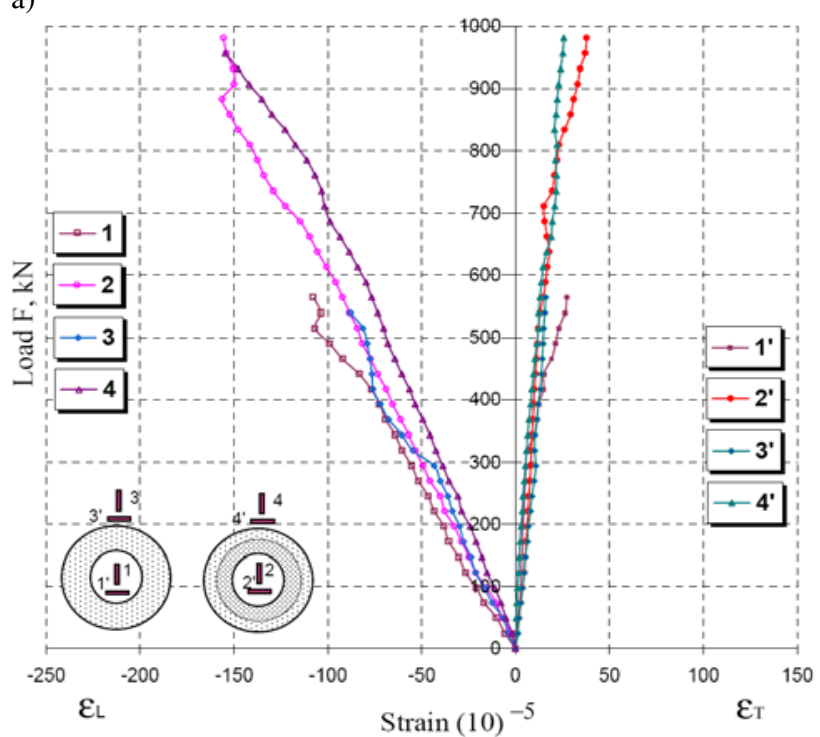

b)

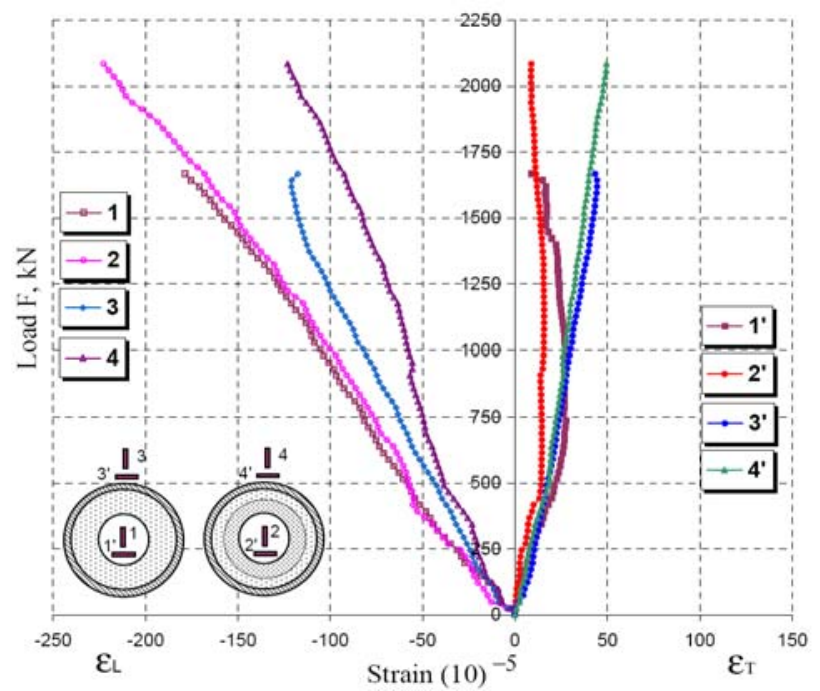

c)

Fig 5. Diagrams $F-\varepsilon_{i}$ for ST (a); CT (b) and CFST (c) elements 
Table 1. Quantities of materials used for manufacturing CT and CFST specimens

\begin{tabular}{|c|c|c|c|c|c|c|c|c|c|}
\hline \multirow[b]{2}{*}{ No } & \multirow[b]{2}{*}{$\begin{array}{l}\text { Length of } \\
\text { specimen, } \\
\text { mm }\end{array}$} & \multirow[b]{2}{*}{$\begin{array}{l}\text { Number of } \\
\text { specimens }\end{array}$} & \multirow[b]{2}{*}{$\begin{array}{c}\text { Initial length of } \\
\text { spun member, } \\
\text { mm }\end{array}$} & \multicolumn{3}{|c|}{ Quantities of materials } & \multirow{2}{*}{$\begin{array}{l}\text { Cement: } \\
\text { aggregate } \\
\text { and } W / C \\
\text { ratio }\end{array}$} & \multirow{2}{*}{$\begin{array}{l}\text { Slump of } \\
\text { concrete } \\
\text { mix, cm }\end{array}$} & \multirow{2}{*}{$\begin{array}{c}\text { Quantity } \\
\text { of water } \\
\text { pressured } \\
\text { out from } \\
\text { mix, kg }\end{array}$} \\
\hline & & & & $\begin{array}{l}\text { Cement, } \\
\text { kg }\end{array}$ & $\begin{array}{c}\text { aggregate, } \\
\mathrm{kg}\end{array}$ & $\begin{array}{l}\text { Water, } \\
\mathrm{kg}\end{array}$ & & & \\
\hline $219 \times 5(1)$ & 437 & 12 & 5540 & 74,1 & 150,5 & $40,2(8,5)$ & \multirow{10}{*}{$\begin{array}{l}1: 2,03 \\
0,543\end{array}$} & 10,0 & 8,3 \\
\hline \multirow{2}{*}{$219 \times 5(2)$} & \multirow{2}{*}{437} & \multirow{2}{*}{12} & \multirow{2}{*}{5540} & 42,4 & 86,1 & $23,0(4,9)$ & & \multirow{2}{*}{10,5} & 6,2 \\
\hline & & & & 37,1 & 75,5 & $20,1(4,2)$ & & & 5,3 \\
\hline & \multicolumn{3}{|c|}{ Total quantity of materials for spun specimens } & 153,6 & 312,1 & 83,3 & & & \\
\hline $\mathrm{C} 219(1)$ & \multirow{3}{*}{$100 \times 100 \times 100$} & 4 & & \multirow{3}{*}{1,9} & \multirow{3}{*}{3,8} & \multirow{3}{*}{1,03} & & 10,0 & - \\
\hline \multirow{2}{*}{ C219(2) } & & 4 & & & & & & \multirow{2}{*}{10,5} & - \\
\hline & & 4 & & & & & & & - \\
\hline P219(1) & \multirow{3}{*}{$400 \times 100 \times 100$} & 3 & & \multirow{3}{*}{7,6} & \multirow{3}{*}{15,2} & \multirow{3}{*}{4,12} & & 10,0 & - \\
\hline \multirow{2}{*}{ P219(2) } & & 3 & & & & & & \multirow{2}{*}{10,5} & - \\
\hline & & 3 & & & & & & & - \\
\hline \multicolumn{4}{|c|}{$\begin{array}{l}\text { Total quantities of materials for concrete prisms and } \\
\text { cubes }\end{array}$} & 11,4 & 22,8 & 4,8 & - & & \\
\hline \multicolumn{4}{|c|}{$\begin{array}{l}\text { Calculated total quantities of materials for cubes, prisms } \\
\text { and spun specimens }\end{array}$} & 340,8 & 692,1 & 145,6 & - & & \\
\hline \multicolumn{4}{|c|}{$\begin{array}{l}\text { Used quantities of materials for cubes, prisms and spun } \\
\text { specimens with a compaction coefficient of } 20 \%\end{array}$} & 409,0 & 830,5 & 174,7 & - & & \\
\hline
\end{tabular}

Table 2. Geometrical parameters and test results of single- and two-layered CFST, CT and ST elements

\begin{tabular}{|c|c|c|c|c|c|c|c|c|c|}
\hline \multirow[b]{2}{*}{ Specimen } & \multicolumn{3}{|c|}{ Steel tube } & \multicolumn{4}{|c|}{ Concrete core } & \multirow{2}{*}{$\begin{array}{c}N_{u, \exp } \\
\mathrm{kN}\end{array}$} & \multirow{2}{*}{$\begin{array}{c}f_{u, \exp }, \\
\mathrm{MPa}\end{array}$} \\
\hline & $\begin{array}{l}t_{a}, \\
\mathrm{~mm}\end{array}$ & $\begin{array}{l}D_{a}, \\
\mathrm{~mm}\end{array}$ & $\begin{array}{c}A_{a}, 10^{-4} \\
\mathrm{~mm}^{2}\end{array}$ & $\begin{array}{l}D_{c e}, \\
\mathrm{~mm}\end{array}$ & $t_{c 1}, \mathrm{~mm}$ & $t_{c 2}, \mathrm{~mm}$ & $\begin{array}{c}A_{c}, 10^{-4} \\
\mathrm{~mm}^{2}\end{array}$ & & \\
\hline 1CFST1 & 5,0 & 220 & 33,8 & 210,0 & 28,5 & - & 162,5 & 1679 & 103,3 \\
\hline 1CFST2 & 5,0 & 219 & 33,6 & 209,0 & 27,0 & - & 154,4 & 1658 & 107,4 \\
\hline 1CFST3 & 4,9 & 220 & 33,1 & 210,2 & 27,1 & - & 155,9 & 1658 & 106,4 \\
\hline \multicolumn{8}{|r|}{$\operatorname{Ave}(3)=$} & 1665,0 & 105,7 \\
\hline 2CFST1 & 5,1 & 219 & 34,3 & 208,8 & 16,0 & 15,1 & 173,6 & 2021 & 116,4 \\
\hline 2CFST2 & 5,1 & 220 & 34,4 & 209,8 & 15,2 & 15,9 & 174,6 & 2066 & 118,3 \\
\hline 2CFST3 & 5,1 & 220 & 34,4 & 209,8 & 16,2 & 15,0 & 175,1 & 2080 & 118,8 \\
\hline \multicolumn{8}{|r|}{$\operatorname{Ave}(3)=$} & 2055,7 & 117,9 \\
\hline 1CT1 & - & - & - & 210,1 & 27,4 & - & 157,2 & 559 & 35,6 \\
\hline $1 \mathrm{CT} 2$ & - & - & - & 211,8 & 26,2 & - & 152,9 & 670 & 43,8 \\
\hline $1 \mathrm{CT} 3$ & - & - & - & 210,4 & 27,1 & - & 155,7 & 653 & 41,9 \\
\hline \multicolumn{8}{|r|}{$\operatorname{Ave}(3)=$} & 627,3 & 40,4 \\
\hline $2 \mathrm{CT} 1$ & - & - & - & 208,8 & 15,5 & 14,0 & 166,2 & 753 & 45,3 \\
\hline 2CT2 & - & - & - & 209,8 & 15,0 & 15,0 & 169,5 & 690 & 40,7 \\
\hline $2 \mathrm{CT} 3$ & - & - & - & 209,6 & 15,0 & 13,7 & 163,1 & 769 & 47,2 \\
\hline \multicolumn{8}{|r|}{$\operatorname{Ave}(3)=$} & 737,3 & 44,4 \\
\hline ST1 & 4,9 & 219 & 33,0 & - & - & - & - & 942 & 285,6 \\
\hline ST2 & 4,9 & 219 & 33,0 & - & - & - & - & 927 & 281,3 \\
\hline ST3 & 5,0 & 220 & 33,8 & - & - & - & - & 942 & 279,0 \\
\hline \multicolumn{8}{|r|}{ Ave(3)= } & 937,0 & 281,9 \\
\hline
\end{tabular}

surfaces. The curves $2,2^{\prime}$ and $4,4^{\prime}$ represent strains measured on double-layered CT members in internal and external surfaces respectively. The same notation of curves is used for CFST elements too. The obtained results of $F-\varepsilon$ relationships for single- and double-layered elements show nearly the same shape and inclination of curves, but failure strains for double-layered CT are nearly twice and for double-layered CFST members by $20 \%$ greater than for single-layered members respectively.

Longitudinal and transversal strains of single- and double-layered CT elements of annular cross-section are of the same shape and inclination respectively, but values at the same compression force are approx by $\sim 25 \%$ less for double-layered elements. For CFST elements only longitudinal strains of concrete are on internal surface and transversal strains on steel tube have the same shapes and inclinations for single- and double-layered elements. Other strains on corresponding surfaces of single- and double-layered members are of different shape and inclination. That confirms an existence of additional interaction between components of double-layered CFST elements, and redistribution of stresses distributes through the thickness of concrete core section. 
It is possible to maintain that behaviour of external concrete layer in 3D stress state like in solid member and internal layer is behaving as in 2D state. Steel tube in both cases may be accepted as in biaxial stress state. Longitudinal strains at internal surface of concrete core are 1,28 for single- and 1,72 times greater for double-layered CFST specimens than longitudinal strains of steel tube. But transversal strains on external surface of steel tube for single- and double-layered elements are $15 \%$ and $53 \%$ respectively lower than on internal concrete core. As longitudinal strains increase, the lateral expansion of concrete core becomes gradually greater than that in $2 \mathrm{D}$ stress state. This shows that redistribution of stresses in multi-layered element increases the strength and ductility of CFST elements.

\subsection{Poisson's ratios of CFST and CT elements}

For behaviour analysis of hollow CFST and CT elements Poisson's ratio and axial force diagrams $F-v$ are presented in Fig 6 a, b. Average value of Poisson's ratio for steel tube was 0,28 .

Poisson's ratio of steel shell and concrete core is changing during load applications. This ratio defined on the base of strains measurements on external and internal surfaces is distributing due to similar shapes in singleand double-layered CFST members (Fig 6b). The curves $F-v$ of CT elements on internal and external surfaces of single- and double-layered members are not of the same shape (Fig 6a). An average value of Poisson's ratio on internal and external surfaces of single- and doublelayered CT elements (Fig 6a) is approx equal to 0,175 . Initial Poisson's ratio values on the internal surface of single-layered elements are less than that on external one, hereupon for double-layered members is opposite. Both surfaces achieve the same values of $v$ at $1 / 3$ of ultimate load of single- and double-layered elements. Surfaces of double-layered CT elements reach the same Poisson's ratio at 0,82 level of the ultimate load. Under an ultimate load concrete core Poisson's ratio value is greatest and on internal surfaces equal to 0,255 for single- and doublelayered CT elements. Maximum values on external surfaces are 0,175 and 0,163 for single- and double-layered elements respectively. Average values of concrete core on internal and external surfaces are 0,15 and 0,18 for single-layered, 0,18 and 0,16 for double-layered elements. From diagram $F-v$ (Fig 6b) for CFST elements maybe noted that maximum values of Poisson's ration are obtained on internal and external surfaces at levels of $1 / 3$ and $1 / 5$ respectively for single- and double-layered members. Minimum values of ratios are obtained at the ultimate load - 0,1 and 0,2 on internal for single-layered, 0,34 on external for double-layered elements. Average values of Poisson's ratio on internal and external surfaces are of 0,25 and 0,38 for single-, 0,29 and 0,42 for doublelayered CFST elements, respectively. Curves 1 and 2 on Figs $6 a, b$ represent the relationships $F-v$ on internal concrete core of single- and double-layered CT and CFST elements respectively, and curves 3 and 4 - on external surfaces. Analysis of curves on Fig $6 \mathrm{~b}$ shows that Pois- son's ratio average values of double-layered CFST elements are greater than those of single-layered members.

For a more detailed analysis of single-and doublelayered CT and CFST elements behaviour $\varepsilon-v$ diagrams were plotted on Figs 7a, b, c and d. Fig 7a represents diagrams of single-layered CT specimens. It can be noted that Poisson's ratio on external surface (curves 1, 1') of CT members (Figs 7a, b) initially starts from maximum and diminishes to its minimum values at ultimate strain, and on internal surface it is an opposite situation (curves 2, 2'): Poisson's ratio initially starts at minimum value and reach it maximum extreme value at ultimate strain. External and internal surfaces achieved the same value of Poisson's ratio at $~ 1 / 2$ level of ultimate strains. Similar behaviour is seen in transversal direction. The initial situation of double-layered CT elements is different in respect of single-layered members (Fig 7b). Poisson's ratio on external surface (curves 1,1 ') reaches maximum value at approx $2 / 3$ of ultimate strain and on internal surface (curves 2,2') reaches maximum value at initial loading stage. At $1 / 2$ and $1 / 3$ of ultimate strain the Poisson's ratio for internal and external surfaces reaches the same value of $0,160-0,165$ at level of $0,85-0,90$ of ultimate strains. For CFST elements (Figs 7c, d) situation differs considerably from that of CT elements. The shapes of these elements diagrams $\varepsilon-v$ on external and internal surfaces are quite similar. Maximum values of Poisson's ratios on external surfaces are reached at initial loading stage at approx level of 0,15 ultimate strains, and minimum values at initial strains. Poisson's ratio on internal surface achieved the maximum value at level 0,35 , and minimum at ultimate strains. This behaviour is typical for single- and double-layered elements.

The difference in behaviour between single- and double-layered CFST elements shows an appearance of interaction. Poisson's ratio of concrete internal surface in single-layered element reaches a lower value than that in the double-layered element.

\subsection{Elasticity modules of CFST and CT elements}

Figs $8 \mathrm{a}, \mathrm{b}$ represent diagrams $E-F$ for single- and double-layered CT and CFST elements, respectively.

Elasticity modulus $E_{\mathrm{CT}}$ of internal (curve 1) and external (curve 3) surfaces of single-layered CT elements does not greatly vary during loading, and its approximate average value is $35,0 \mathrm{GPa}$ for both surfaces. For doublelayered CT elements at initial loading stage, elasticity modulus on internal surface reaches its ultimate value $(63,7 \mathrm{GPa})$, and diminishes to a mean value with load increasing at $1 / 5$ of ultimate load approach.

It may be noted that a mean value of $E_{\mathrm{CT}}$ on external surface (curve 4 on Fig 8a) of double-layered CT elements is twice greater than that of single-layered ones. That may be explained by a higher density of external concrete layer [4] achieved because of centrifuging process. Therefore the curve 2 (Fig 8a) coincides with the curves of single-layered elements and shows that no changes in stress state or in structure have appeared comparing with the ones of single-layered elements. For a 


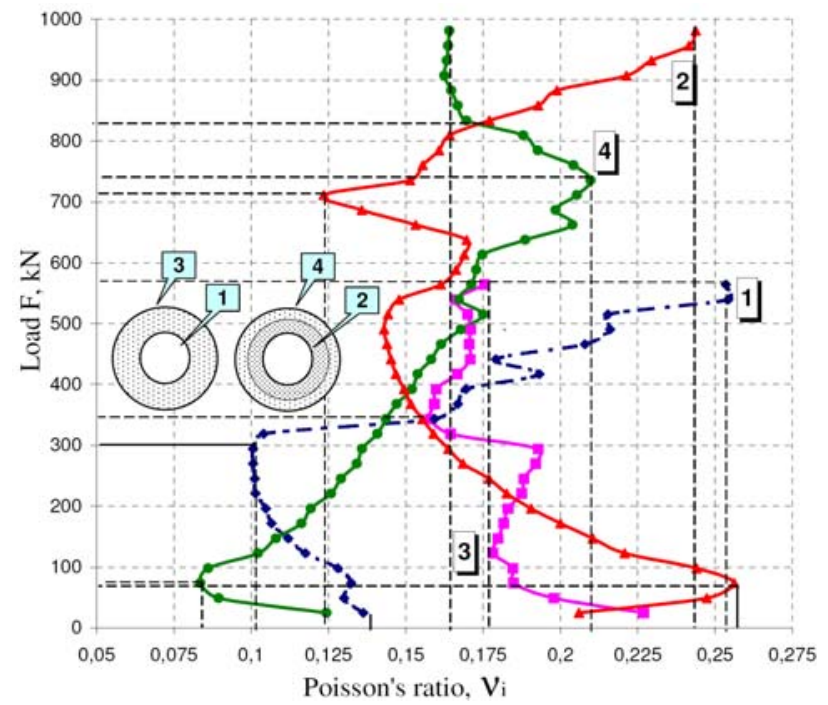

a)

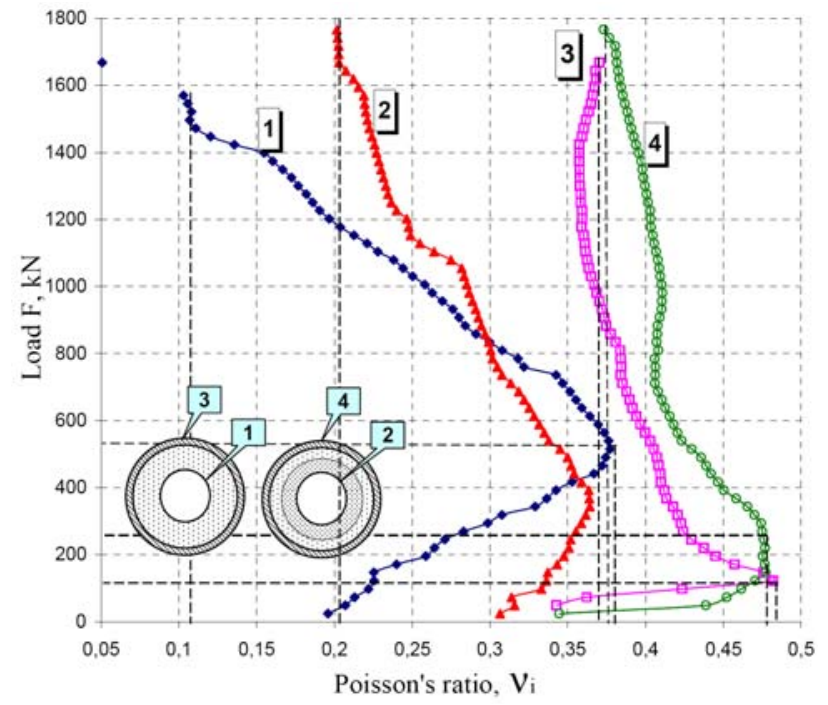

b)

Fig 6. Diagrams $F-v($ a) for single- and (b) two-layered CT CFST elements

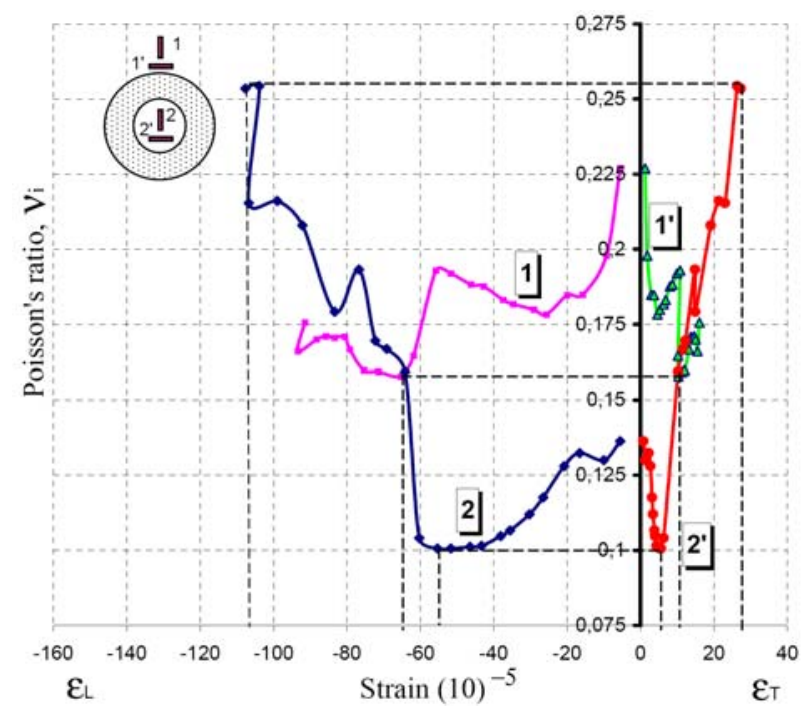

a)

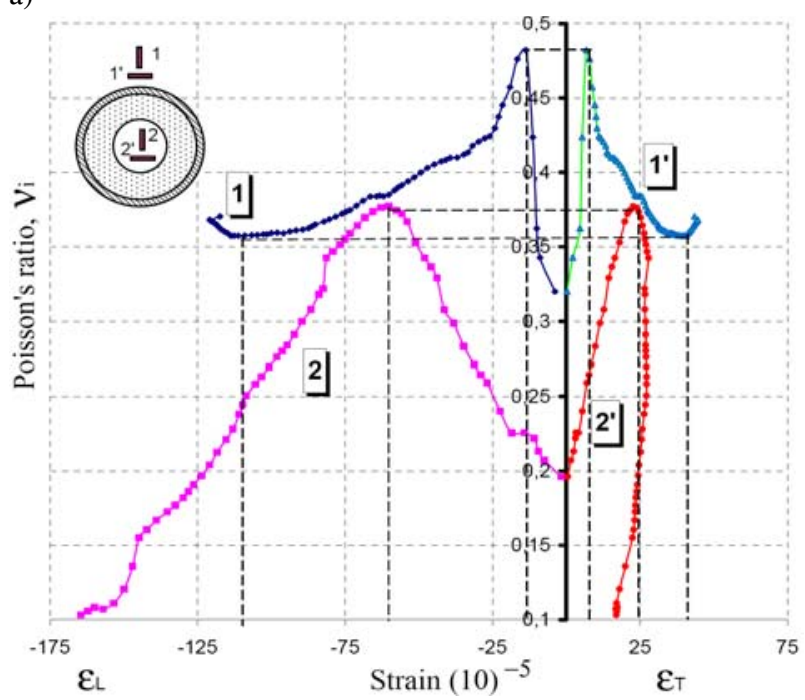

c)

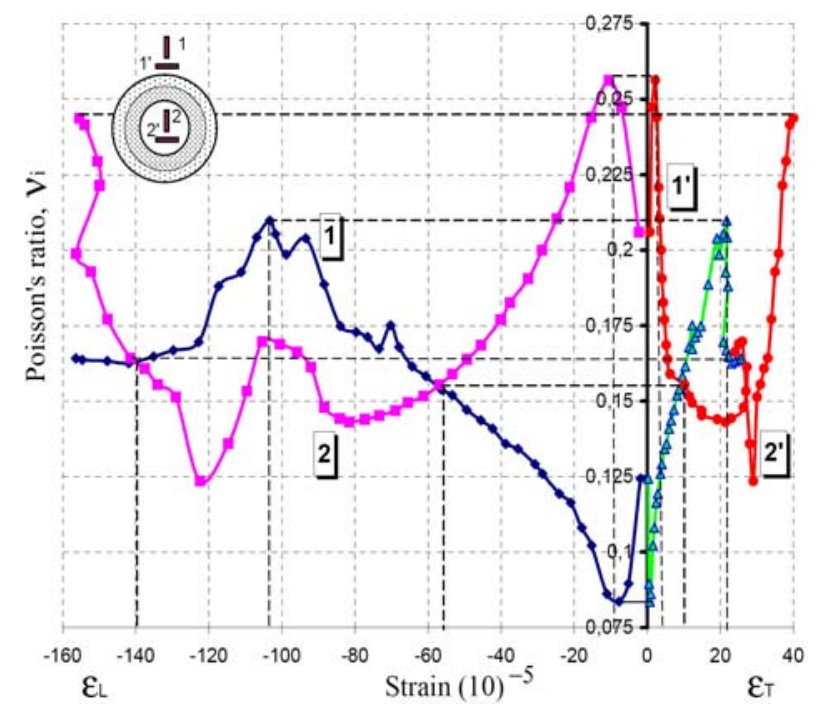

b)

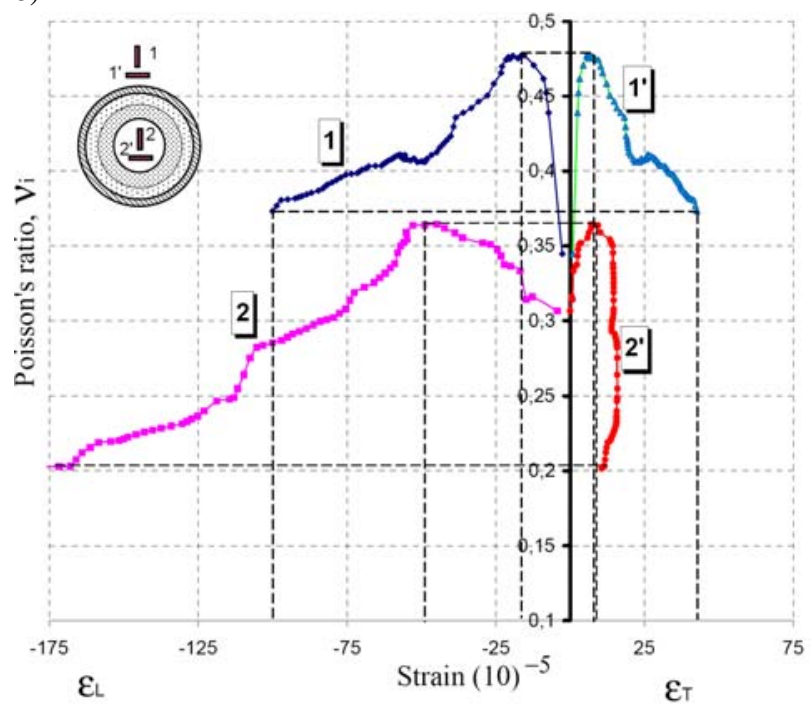

d)

Fig 7. Diagrams $v-\varepsilon$ of (a) single, (b) double-layered CT elements, (c) single- and (d) double-layered CFST elements 


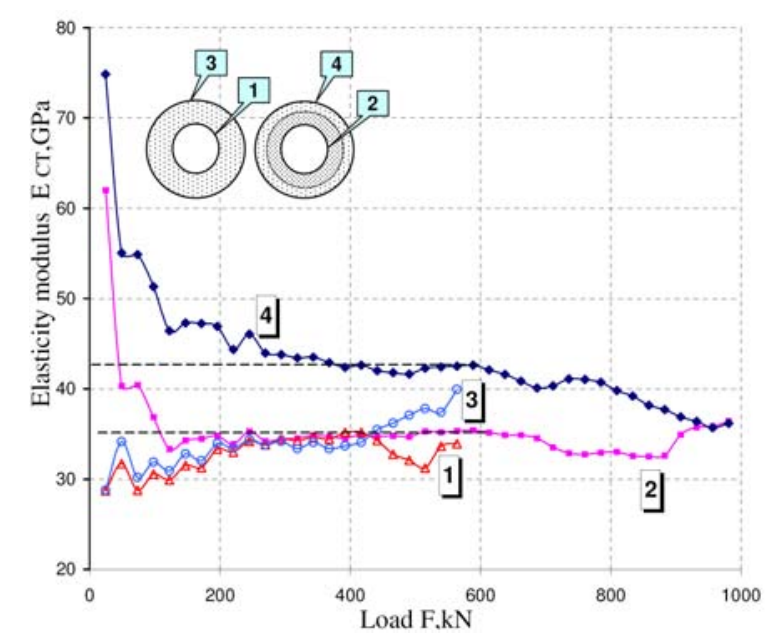

a)

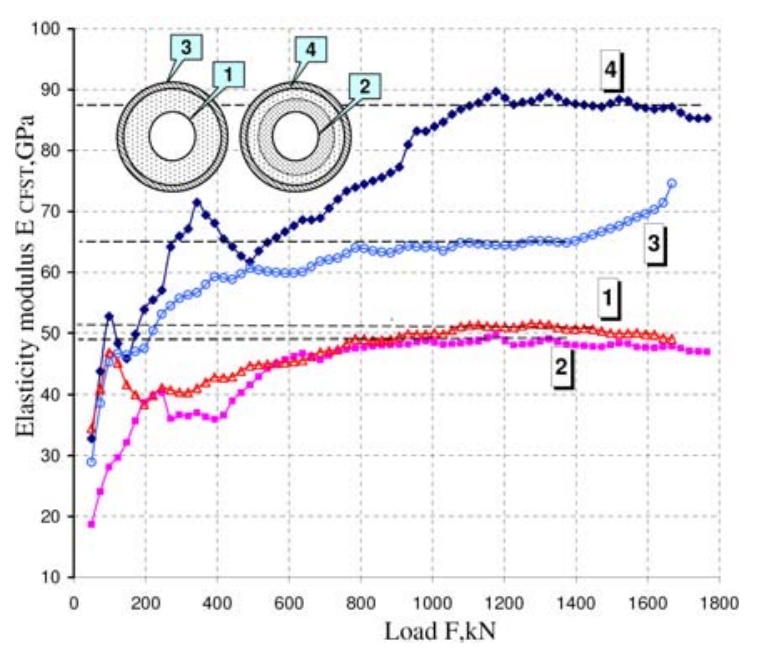

b)

Fig 8. Diagrams $E_{C T}-F$ of CT (a) and $E_{C F S T}-F$ of CFST (b) elements

single-layered CFST elements situation is the same as for the CT elements. Curves of elasticity modulus on internal (curves 1 and 3 on Fig 8a) surfaces repeat each other and reach the mean value of 48,5 $\mathrm{GPa}$. Differently from $\mathrm{CT}$ elements, elasticity modulus curves $E_{C F S T}$ on external surface (curve 3 on Fig 8b) of single-layered CFST elements repeats only the shape of curves 1 and 2 (Fig 8b) with $\sim 15 \mathrm{GPa}$ a greater value. This shows that a greater density of external concrete layer [4] is not the main reason of greater $E_{C F S T}$ because an interaction between layers causes stress redistribution in elements; therefore it becomes more ductile and may resist the greater strains. It may be noted that $E_{C F S T}$ value of external steel shell in double-layered CFST elements (curve 4 on Fig $8 b$ ) has a greater value than the one of singlelayered members rising up with load reaching its peak value of $\sim 90 \mathrm{GPa}$ close to failure.

For determining the $E_{C T}, E_{C F S T}$ parameters Hooke's law and total cross-section area (area of cross-section for internal and for external surfaces was taken as total area of the whole cross-section) were used.

Elasticity modulus of ST elements was determined and corresponds to $212 \mathrm{GPa}$ value.

\subsection{Micro-cracking and volumetric strains of CT and CFST element}

According to [14, 16-17] micro-cracking of concrete starts significantly increasing at parametric point $f_{c r}^{v}$, when concrete volumetric strains $\varepsilon_{v}$ or its relative volumetric increment $\Delta \theta$, calculated by (1), reach zero value. The experimental results (Figs 9a, b) show that $\Delta \theta$ of single-layered CT and CFST elements reach zero value at level of approx $0,97 \sigma_{C F S T(C T)} / f_{u}$ (curve 1). Hereupon double-layered elements do not cross zero axes at all. It shows that in single-layered CFST elements micro-cracks consolidate $97 \%$ of ultimate strength, and failure of structural elements takes place soon.

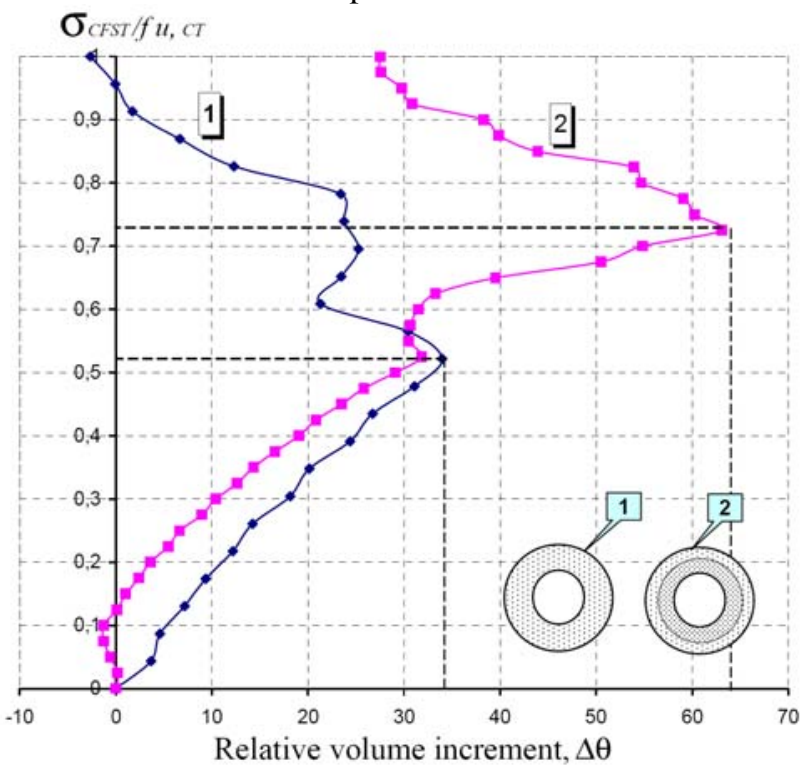

a)

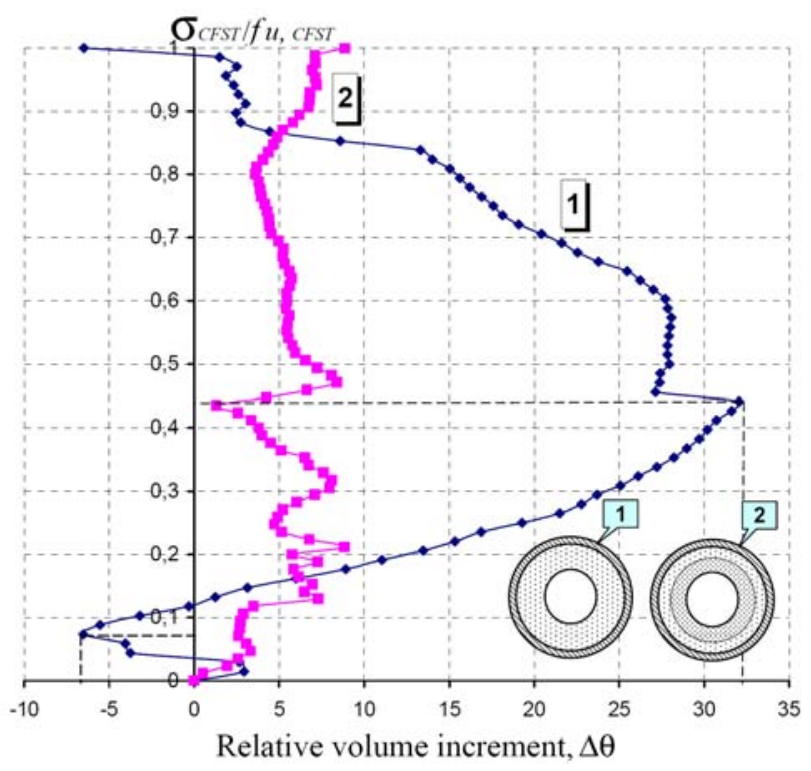

b)

Fig 9. Diagrams $\Delta \theta-\sigma_{i} / f_{u}$ for CT (a) and CFST (b) elements 
Hereupon macro-cracks in double-layered elements appear only on internal layer, and in external layer after inspection no macro-cracks were found at all (curves 2 in Figs 9a, b). Collapse of these elements takes place later than of single-layered ones because cracks on their internal layer do not develop into an external concrete layer; just propagation of cracks proceed along the perimeter of contact surface between the two concrete layers.

Diagrams of volumetric increments $\Delta \theta$ of CT singleand double-layered elements are approximately of the same value and shape until lower micro-cracking parametric point of $0,52 \sigma_{C T} / f_{u}$ value. After this point $\Delta \theta$ of double-layered elements starts growing up faster and at $0,72 \sigma_{C T} / f_{u}$ its value starts to decrease. Volume of single-layered CT elements starts to decrease at $\sim 0,57 \sigma_{C T} / f_{u}$ and reaches a zero increment at about $0,97 \sigma_{C T} / f_{u}$, that shows an appearance of an upper limit of micro-cracking $f_{c r}^{v}$. As it was mentioned above, $\Delta \theta$ of double-layered elements does not cross zero axes at all.

Differently from diagrams of CT elements the diagrams of CFST show that maximum volumetric increment of double-layered members is increasing less than that of single-layered CT elements. Relative volumetric increment $\Delta \theta$ of single-layered CFST element reaches higher value than that of the double-layered elements; therefore situation is opposite with respect of CT elements. Lower parametric point $f_{c r}^{0}$ for CFST members is reached at $0,44 \sigma_{C F S T} / f_{u}$ level.

Comparing our own test results with the results of $[16,17]$, it can be noted that behaviour of single-layered CT and CFST elements is nearly the same, but in [16, 17] CT elements reach the second parametric point at level $0,82 \sigma_{C T} / f_{u}$ and CFST elements - at $0,75 \sigma_{C F S T} / f_{u}$. Such differences in these results may be explained that an extra-fine grain concrete mix was used for authors' own specimens, and for specimens of [16, 17] an ordinary concrete mix was applied.

\section{Conclusions}

Theoretical and experimental investigations show that behaviour of hollow CFST elements is more complicated than that of solid ones, because of complex stress states none of stresses in hollow concrete core are evenly distributed through the thickness of its cross-sections. For single-layered CFST elements the triaxial stress state is achieved only at the contact surface between the concrete core and steel shell. An internal hollow concrete core of double-layered CFST elements is in the same stress state as of single-layered members, but an external layer is analysed as being in 3D stress state.

Researchers [18, 19] using materials of different properties tried to explain and evaluate this phenomenon by mathematical equations (4-7). According to [18], during loading between neighbouring layers of concrete core in normal stress diagrams at place of interaction surface the step appears, and authors [18, 19] suggest how to evaluate this step.
Test results (Table 2, Figs 5-9) improve the propositions of $[5,18,19]$ that multi-layered elements had greater load-bearing capacity with respect to singlelayered hollow CFST elements. This increase in strength is explained by appearance of additional interaction between neighbouring concrete layers under loading conditions. For double-layered CFST members greater deformations of an internal layer cause confinement of an external layer; therefore their stresses redistribute and an external concrete layer may be analysed as in $3 \mathrm{D}$ stress state.

Behaviour of single- and multi-layered CFST elements differs essentially. Multi-layered elements resist not only greater loads but, being more ductile, they have better such characteristics as modulus of elasticity, density etc. Failure of such elements is more ductile, therefore structures from such elements may be used more safely.

Experimental investigations presented in this article may help for further investigations and design of hollow single- and multi-layered CFST elements. Prediction of their behaviour at various loading situations is possible.

\section{References}

1. GOURLEY, B.; TORT, C.; HAJJAR, J. F. and SCHILLER, P. A Synopsis of Studies of the Monotonic and Cyclic Behavior of Concrete-Filled Steel Tube BeamColumns. Structural Engineering Report No ST-0-4, Dept of Civil Engineering Institute, Technology University of Minneapolis MN, USA, 2001. 263 p.

2. KVEDARAS, A. K. and DOLGOPOLOVAS, V. Structural member of strut type. SU 1250630 A1. World invention bulletin, No 30, Moscow, 1986, p. 17-20 (in Russian).

3. SHAMS, M. Non-linear evaluation of concrete-filled steel tubular columns. PhD thesis, New Jersey Institute of Technologies, New Jersey, USA, 1997. 237 p.

4. ACHVERDOV, I. N. Oppressive reinforced concrete spinned tubes. Moscow: Stroyizdat, 1967. 164 p. (in Russian).

5. KVEDARAS, A. K. Theory and practice of concrete filled steel tubes. Habilitation thesis, Vilnius Gediminas Technical University, Vilnius, 1999. 82 p. (in Lithuanian).

6. SEWEL, J. S. Columns for buildings. Engineering News, 1902, 48(17), p. 36-39.

7. KLÖPPEL, K. and GODER, W. Traglastversuche mit ausbetonierten Stahlrohen und Aufstellung einer Bemessungsformel. Der Stahlbau, 1957, 26(1), p. 1-10.

8. SALANI, H. R. and SIMS, J. R. Behavior of Mortar Filled Steel Tubes in Compression. Journal of American Concrete Institute, 1964, 61(10), p. 1271-1283.

9. FURLONG, R.W. Design of Steel-Encased Concrete Beams Columns. Journal of the Structural Division, 1968, 94(1), p. 267-281.

10. JOHANSSON, M. and GYLLLTOFT, K. Mechanical Behaviour of Circular Steel-Concrete Composite Stub Columns. Journal of Structural Engineering, 2002, 128(8), August, p. 1073-1081.

11. SHAN-TONG, Z.; SUMEI, Z. A new method from China to determine load-carrying capacity for CFST members. In Proc of an Engineering Foundation Conference: Composite Construction in Steel and Concrete II, Potosi, Mis- 
souri, USA, 14-19 June 1998. Ed. by D. Darwin and D. Dale Buckner, 1998, p. 499-511.

12. MARKAUSKAS, D. and KAČIANAUSKAS, R. Compacting of particles for biaxial compression test by the discrete element method. Journal of Civil Engineering and Management, 2004, 12(2), p. 153-161.

13. BRAUNS, J. and ROCENS, K. The effect of material strength on the behaviour on concrete-filled steel elements. Journal of Civil Engineering and Management, 2004, 10(3), p. 177-182.

14. JOHANSSON, M. Composite Action and Confinement Effects in Tubular Steel-Concrete Columns. PhD thesis, Chalmers University of Technology, Göteborg, Sweden, 2002. 77 p.

15. BERG, O. J. Physical foundations of concrete and reinforced concrete strength theory. Moscow: Gosstroyizdat, 1962. 110 p. (in Russian).

16. KVEDARAS, A. K. On determining concrete microcracking limits in tube specimens. Reinforced Concrete Structures, 6(1), 1974, p. 81-90 (in Russian).

17. KVEDARAS, A. K. Concrete crack resistance peculiarities in axially compressed composite members. Reinforced Concrete Structures, 1987, 15(1), p. 103-111 (in Russian).
18. RZHANICYN, A. R. Built-up bars and plates. Moscow: Stroyizdat, 1986. 315 p. (in Russian).

19. MUSHELESHVILI, N. I. Some fundamental problems of mathematical theory of elasticity. Moscow: Nauka, 1966. 708 p. (in Russian).

20. ROEDER, C. W.; CAMERON, B. and BROWN, C. B. Composite Action in Concrete Filled Tubes. Journal of Structural Engineering, 1999, 125(5), p. 477-484.

21. VIRDI, K. S. and DOWLING, P. J. Bond Strength in Concrete filled Steel Tubes. In Proc IABSE P-33/80, Zurich, Switzerland, 1980, p. 125-139.

22. SHAKIR-KHALIL, H. Resistance of concrete-filled steel hollow tubes to pushout forces. The Structural Engineering, 1993, 71(13), p. 234-243.

23. SHAKIR-KHALIL, H. Pushout strength of concrete-filled steel hollow section. The Structural Engineering, 1993, 71(13), p. 230-233.

24. KILPATRICK, A. and D RANGAN, B.V. Influence of Interfacial Shear Transfer on Behavior of Concrete-Filled Steel Tubular Columns. ACI Structural Journal, 1999, 96(72), p. 642-648.

\section{TUŠČIAVIDURIŲ BETONŠERDŽIŲ PLIENINIU VAMZDINIỤ STRYPŲ ELGSENA}

\section{A. Kuranovas, A. K. Kvedaras}

\section{Santrauka}

Dažniausiai naudojamų i̇vairiai apkrautų pilnavidurių betonšerdžių plieninių vamzdinių elementų elgsena teoriškai pakankamai išsamiai išanalizuota ir pagrịsta bandymais. Tuščiaviduriai betonšerdžiai plieniniai strypiniai elementai (TBPS) yra viena iš tokių kompozitinių elementų rūšių. Pasaulyje naudojami įvairūs norminiai dokumentai ir projektavimo rekomendacijos yra pritaikytos pilnaviduriams BPS. Tuščiavidurių elementų, kurie neretai yra efektyvesni nei pilnaviduriai, tyrimų ir jų elgsenos teorin s analiz s n ra gausu. Apkrovimo metu, kai pasiekiamas tam tikras įtempių būvis, tarp kompozitinio elemento komponentu atsiranda sąveika. Tod 1 susikuria sud tingesnis itempių būvis bei padid ja elemento laikomoji galia. Ši sąveika atsiranda d 1 naudojamų medžiagų skirtingų savybių, tokių kaip Puasono koeficientas, tamprumo modulis ir t. t. Straipsnyje pateiktos sud tingo i̇tempių būvio atsiradimo priežastys bei jų elgsenos, veikiant ivvairioms gniuždomosioms apkrovoms, ypatumai. Aprašyti ir išanalizuoti bandymo metu gauti rezultatai, kurie pateikti grafikų ir lentelių pavidalo. Betoninių ir kompozitinių vienasluoksnių ir dvisluoksnių TBPS elementų elgsenos panašumai ir skirtumai aptarti ir palyginti su pilnaviduriais BPS.

Reikšminiai žodžiai: kompozitin s konstrukcijos, betonšerdžiai plieniniai vamzdžiai, tuščiaviduriai, centrifugavimas, sąveika tarp komponentų, elgsena, betono triašis būvis, Puasono koeficientas.

Artiomas KURANOVAS. PhD student at Dept of Steel and Timber Structures. Vilnius Gediminas Technical University, Saul tekio al. 11, LT-10223 Vilnius, Lithuania. Ph 2745228, fax 2398800. E-mail: artiomas.kuranovas@ stst.vtu.lt. A graduate of Civil Engineering at Vilnius Gediminas Technical University (2002). MSc of Civil Engineering (2004) at Vilnius Gediminas Technical University. Research interests: structural mechanics, composite elements and behaviour of their components, engineering software for structural elements design.

Audronis Kazimieras KVEDARAS. Prof Dr Habil at the Dept of Steel and Timber Structures, Director of the Innovatory Scientific Institute of Special Structures "Kompozitas" of Vilnius Gediminas Technical University, Saul tekio al. 11, LT-10223 Vilnius, Lithuania. E-mail: akve@st.vtu.lt.

Research interests: steel, composite steel-concrete and timber structures. Member of IABSE and ASCCS, NATO invited expert $(1996,2000)$. 